\begin{tabular}{cc|c}
\hline Tar. Bil. Der. & Tarm Bilimleri Dergisi & Journal of Agricultural Sciences \\
& $\begin{array}{c}\text { Dergi web sayfası: } \\
\text { www.agri.ankara.edu.tr/dergi }\end{array}$ & Journal homepage: \\
& www.agri.ankara.edu.tr/journal
\end{tabular}

\title{
Morphological Characterization of Bottle Gourd (Lagenaria siceraria (Molina) Standl.) Germplasm and Formation of a Core Collection
}

\author{
Adem TAŞ̧, Halit YETIŞín ${ }^{\mathrm{b}}$, Nihal DENLII ${ }^{\mathrm{a}, \mathrm{c}}$, Kahraman GÜRCAN ${ }^{\mathrm{d}}$ \\ ${ }^{a}$ Çukurova University, Faculty of Agriculture, Department of Horticulture, Adana, TURKEY

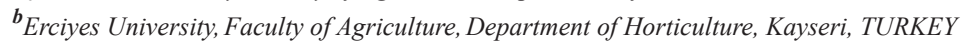 \\ ${ }^{c}$ Alata Horticultural Research Station, Ministry of Food, Agriculture and Livestock, Mersin, TURKEY \\ ${ }^{\boldsymbol{d}}$ Erciyes University, Faculty of Agriculture, Department of Biotechnology, Kayseri, TURKEY
}

\section{ARTICLE INFO}

Research Article DOI: 10.15832/ankutbd.413668

Corresponding Author: Kahraman GÜRCAN, E-mail: kgurcan@erciyes.edu.tr, Tel: +90 (352) 4379315

Received: 09 April 2018, Received in Revised Form: 24 May 2018, Accepted: 07 June 2018

\begin{abstract}
Bottle gourd [Lagenaria siceraria (Molina) Standl.] genotypes were collected from different parts of Turkey and a core collection (CC) was established based on morphological characteristics. The collection was grown for morphological characterization and seed multiplication. Seeds were produced from 322 genotypes (Entire Population- EP) representing diversity of entire country by selfing and the accessions were characterized for 25 quantitative and 21 qualitative morphological characteristics. Important variation was observed in fruit size, cotyledon dimensions, leaf dimension, flower size, fruit length $(8.7-155.7 \mathrm{~cm})$, fruit shape (flat-elongate), seed weight $(3.8 \mathrm{~g} / 100 \mathrm{seeds}-38 \mathrm{~g} / 100 \mathrm{seeds})$ among accessions as previously reported. UPGMA cluster, and principal component analyses cluster of quantitative and qualitative characteristics of EP were assayed. Results of the assays together with geographic origin of the genotypes were analyzed to establish a core population (CC) consisting of 100 genotypes. High correlation between the CC and the $\mathrm{EP}(\mathrm{r}=0.974$ for normalized Mantel Statistic $\mathrm{Z})$ demonstrated that $\mathrm{CC}$ represents the most of total genetic variation with minimum redundancy in bottle gourd germplasm of Turkey. The CC will enable efficient and cost-effective management and utilization of bottle gourd germplasm.

Keywords: Core collection; Genetic resources; Qualitative; Quantitative; Turkey
\end{abstract}

\section{Introduction}

Bottle gourd, calabash [Lagenaria siceraria (Molina) Standl.] belongs to the Cucurbitaceae family, is generally accepted as "the white-flowered gourd" due to its white petals. L. siceraria, an annual, monoecious and vigorously climbing species, is one of the earliest domesticated plant species for human utilization (Decker-Walters et al 2004). Bottle gourd is extensively distributed, and ocean currents are believed to have mediated migration of L. siceraria from Africa to America, and consequently the species is divided into two subspecies: Asian bottle gourd [L. s. subsp. asiatica (Kobyakova) Heiser] and American/African bottle gourd (L. s. subsp. siceraria) (Kistler et al 2014). In Europe, bottle gourd has been a known species 
in northern Italy since the Iron Age (Schlumbaum \& Vandorpe 2012). Whether bottle gourd originated from Africa or Asia is the subject of studies all over the world including Turkey; no historical finding about bottle gourd has been reported, however, recent molecular analysis suggested that Turkish bottle gourds are mix of African and Asian bottle gourds (Gürcan et al 2015).

The mature dried fruits of bottle gourds are used by people throughout the world as containers, kitchen utensils, musical instruments, for artistic purposes or in some coastal regions, fishing net holders (Decker-Walters et al 2004). Young leaves, shoots, seeds, fresh tendrils, shoot and leaves have been also utilized for cooking and some therapeutic aims (Loukou et al 2007). Additionally, L. siceraria has a potential to be used rootstock for watermelon since it is likely to have resistance against different biotic and abiotic stress factors including Fusarium wilt (Yetisir et al 2003), salinity and water-logging of soil (Yetisir \& Uygur 2009).

Collection, characterization and presentation of genetic resources, and their use by breeders and producers provide a clear path to achieve sustainable agriculture (Given 1987). The conserving plant germplasm has been remarkably progressed in the last decades. In many cases the increasing number of germplasm collections has become to limit their accessibility and utilization in plant breeding and research. Difficulties related to utilization of large germplasm in research purposes led the researchers to establish "core collections" (CC) which does not replace the existing collection, but it is off limits size and chosen to represent the genetic diversity of a large collection (Frankel 1984). Several recent studies on collection and evaluation of bottle gourd genetic resources have been conducted based on traits in USA (Decker-Walters et al 2004), Kenya (Morimoto et al 2005), Serbia (Mladenović et al 2012) and Turkey (Yetisir et al 2008). In the previous study (Yetisir et al 2008) bottle gourds were collected in just Mediterranean region of the country. The study demonstrated in high morphological variation and indicated importance of germplasm collection over the entire country. Here a) we collected and studied morphological (quantitative and qualitative traits) characterization of the bottle gourds in the all regions of the Turkey where bottle gourds grown and b) additionally, a CC consisting of 100 genotypes were established the first time. This study is the most comprehensive on the collection and morphological characterization of Turkish bottle gourd accessions.

\section{Material and Methods}

\subsection{Collection of bottle gourds and morphological characterization}

Bottle gourd genotypes used in this study were collected under two projects (TOVAG 3216 and TOVAG 1110117) financially supported by TUBITAK and introduced from different countries. Additionally, bottle gourd accessions obtained from international gene banks were investigated in this study. Available seeds (maximum up to 24 ) of the collected 418 genotypes were planted on March $10^{\text {th }} 2012$ in multi-pots filled with a mixture of perlite and peat (1:2) in a greenhouse at the Alata Horticultural Research Station in Erdemli, Mersin. The experimental area receives annual average rainfall of $500-600 \mathrm{~mm}$ and the soil characteristics are sandy-loam with a low level of lime. Ten seedlings for each accession with 2-3 true leaves were planted into the field with $3 \times 0.5 \mathrm{~m}$ spacing.

Following the soil analysis report, $50 \mathrm{~kg} \mathrm{~N} \mathrm{ha}^{-1}$, $100 \mathrm{~kg} \mathrm{P}_{2} \mathrm{O}_{5} \mathrm{ha}^{-1}$ and $50 \mathrm{~kg} \mathrm{~K}_{2} \mathrm{O} \mathrm{ha}^{-1}$ were added to soil during soil tillage as base fertilizer. Water was applied by drip irrigation and an additional $50 \mathrm{~kg}$ $\mathrm{N} \mathrm{ha}^{-1}$ and $50 \mathrm{~kg} \mathrm{~K}_{2} \mathrm{O}$ ha $^{-1}$ fertilizers were provided by fertigation methods during the growing period. All measurements and observations were made on three representative plants for each genotype. Each accession was characterized for 25 quantitative (Table 2) and 21 qualitative traits (Table 3) according to the descriptor list published by the Biodiversity International for Cucurbitaceae (2007). 


\subsection{Data analyzing and selection of accessions for core collection}

After obtaining characteristic values for the successfully grown bottle gourds, the phylogenetic relationships among bottle gourds were analyzed by unweighted pair group method arithmetic average (UPGMA) and by principal component analysis (PCA). A morphological distance matrix based on all traits was generated by applying the Euclidean coefficient, which was subsequently used for the preparation of a UPGMA dendrogram with the Numerical Taxonomy Multivariate Analysis System (NTSYS-pc) version 2.1 software package (Exeter Software, Setauket, NY, USA) (Rohlf 2000). For the PCA, the data from the entire population (EP) were analyzed using XLSTAT Statistical Analysis Software together with Pearson correlation coefficient (Kovach Computing Service 2013) based on the 25 quantitative and 21 qualitative variables. The UPGMA dendrogram, PCA, and geographic origin of the gourds were used to select establishing a CC representing genetic variation of the entire bottle gourds. All exotic accessions and the Turkish accessions with the most extreme traits were included in the CC. Source and accession numbers of $\mathrm{CC}$ genotypes can be seen at Figure 2. Correlation between the EP and CC were tested by producing and comparing the distance matrices using Mantel test of NTSYS-pc software, which is performed by Pearson product-moment correlation coefficient " $r$ ".

\section{Results and Discussion}

Of the total 418 accessions including 380 Turkish accessions and 38 exotic accessions, seed of 96 accessions did not germinate and the remaining accessions germinated and produced healthy intact plants. A total of 322 produced seedlings and were grown in the experiment field successfully. Of these 322 accessions, 292 were Turkish and the remaining 30 accessions were exotic. Seeds produced from these 322 accessions were deposited in D8 Seed Bank, Ankara, Turkey, (http://www. d8seedbank.org/ContactUs.aspx) and available for breeders and researchers upon request. Twenty-five quantitative and 21 qualitative characteristics were investigated for these 322 accessions resulting in a significant variation among the Turkish and exotic accessions (Table 1. and 2.). The fold difference between minimum and maximum values for the quantitative traits ranged from 1.6 (blooming time for male and female flower) to 15 (fruit length) folds. Interestingly, fruit dimension varied from $8.7 \mathrm{~cm}$ to $155.7 \mathrm{~cm}$ in length while fruit diameters ranged from $4.6 \mathrm{~cm}$ to $27.7 \mathrm{~cm}$. Seed size also showed notable variation with about 10 fold differences between minimum and maximum value of 100 seed weight. A remarkable range of variation was also identified in seedling, leaf and other fruit characteristics: hypocotyl length (1.4$9.9 \mathrm{~cm})$, leaf length $(8.3-24.6 \mathrm{~cm})$, male flower width $(2.6-13.1 \mathrm{~cm})$, female flower length $(3.8-$ $11.8 \mathrm{~cm})$, petiole length $(5.5-30.5 \mathrm{~cm})$, and fruit shell thickness (2.8-16.3 mm).

With respect to qualitative characteristics, plant growth habit (all prostrated), corolla color (all white), sex type (all monecious) and tendril shape and branching (all branched and coiled) did not show differences. However, the remaining traits exhibited notable variation and were separated into several different classes (Table 2). Nine observed traits distributed in three classes while seven observed characteristics separated into four classes. The highest-class number was identified in fruit shape with nine classes (Round, elongated, pyriform, cylindrical, dumbbell, elliptical, flattened, curved, and crooked neck) followed by five classes in leaf shape (oval, round, kidney, heart, and slightly lobed) and pattern of secondary color of fruit skin (Absent, speckled, spotted, streaked, and bisectional). Prior studies showed that Turkey is not the genetic origin of L. siceraria, and the bottle gourds could have been introduced from both Africa and Asia through multiple gateways (Gürcan et al 2015). However, present study confirmed that Turkish bottle gourd germplasm has still a significant variation. At present study, the most obvious phenotypical difference was found in fruit shape and volume. Significant variability of seed and fruit characteristics of bottle gourd accessions from different part of Kenya 
Table 1- Minimum, maximum and mean values for 25 quantitative variables of the entire and core collection of bottle gourd genotypes in the Turkish germplasm collection

\begin{tabular}{|c|c|c|c|c|c|c|}
\hline \multirow{2}{*}{ Characteristics } & \multicolumn{2}{|c|}{ Minimum } & \multicolumn{2}{|c|}{ Maximum } & \multicolumn{2}{|c|}{ Mean $\pm S E$} \\
\hline & $E P$ & $C C$ & $E P$ & $C C$ & $E P$ & $C C$ \\
\hline Hypocotyl diameter (mm) & 1.5 & 1.7 & 4.4 & 4.4 & $2.8 \pm 0.4$ & $2.9 \pm 0.4$ \\
\hline Hypocotyl length (cm) & 1.4 & 2.1 & 9.9 & 8.2 & $4.2 \pm 1.3$ & $4.2 \pm 1.2$ \\
\hline Cotyledon length (cm) & 2.3 & 4.8 & 7.6 & 7.5 & $5.7 \pm 0.9$ & $5.8 \pm 0.8$ \\
\hline Cotyledon width (cm) & 1.5 & 2.4 & 4.3 & 4.0 & $3.13 \pm 0.4$ & $3.16 \pm 0.4$ \\
\hline Leaf length $(\mathrm{cm})$ & 8.3 & 8.3 & 24.6 & 20.1 & $13.8 \pm 2.1$ & $14.2 \pm 2.3$ \\
\hline Leaf width $(\mathrm{cm})$ & 8.9 & 8.9 & 26.1 & 26.0 & $16.4 \pm 3.0$ & $16.9 \pm 3.8$ \\
\hline Petiole length (cm) & 5.5 & 6.2 & 30.5 & 29.8 & $14.4 \pm 3.7$ & $14.7 \pm 3.8$ \\
\hline Petiole diameter (mm) & 2.5 & 2.5 & 11.0 & 10.0 & $6.0 \pm 1.3$ & $6.1 \pm 1.3$ \\
\hline Main stem diameter (mm) & 3.9 & 3.9 & 15.3 & 14.4 & $10.0 \pm 1.6$ & $9.8 \pm 1.7$ \\
\hline Internode length $(\mathrm{cm})$ & 8.4 & 8.1 & 25.9 & 25.9 & $13.2 \pm 2.4$ & $13.5 \pm 2.8$ \\
\hline Male flower length $(\mathrm{cm})$ & 3.1 & 3.1 & 5.9 & 5.3 & $4.3 \pm 0.5$ & $4.2 \pm 0.6$ \\
\hline Male flower width (cm) & 2.6 & 3.8 & 13.1 & 12.4 & $5.5 \pm 0.9$ & $5.5 \pm 1.0$ \\
\hline Ovarium diameter $(\mathrm{mm})$ & 4.0 & 4.0 & 14.6 & 14.6 & $9.2 \pm 1.8$ & $9.3 \pm 1.8$ \\
\hline Ovarium length (mm) & 1.6 & 1.6 & 8.3 & 6.7 & $3.3 \pm 0.8$ & $3.2 \pm 0.8$ \\
\hline Female flower length $(\mathrm{cm})$ & 3.8 & 3.8 & 11.8 & 8.9 & $5.9 \pm 1.0$ & $5.9 \pm 1.4$ \\
\hline Female flower width $(\mathrm{cm})$ & 3.0 & 3.2 & 7.6 & 7.0 & $5.0 \pm 0.7$ & $4.9 \pm 0.7$ \\
\hline Male flower blooming time (DAS) & 51.0 & 51.0 & 80.0 & 80.0 & $63.0 \pm 5.9$ & $63.4 \pm 6.2$ \\
\hline Female flower blooming time (DAS) & 51.0 & 51.0 & 86.0 & 86.0 & $66.0 \pm 6.6$ & $65.7 \pm 7.1$ \\
\hline Fruit length $(\mathrm{cm})$ & 8.7 & 8.7 & 155.7 & 130.5 & $54.5 \pm 18.8$ & $53.9 \pm 1.7$ \\
\hline Fruit diameter $(\mathrm{cm})$ & 4.6 & 2.3 & 27.7 & 53.0 & $16.3 \pm 3.7$ & $8.6 \pm 4.9$ \\
\hline Fruit shell thickness (mm) & 2.8 & 2.8 & 16.3 & 16.3 & $6.8 \pm 2.0$ & $6.8 \pm 2.3$ \\
\hline Seed length $(\mathrm{cm})$ & 0.7 & 0.7 & 2.5 & 2.5 & $1.8 \pm 0.2$ & $1.8 \pm 0.2$ \\
\hline Seed width $(\mathrm{cm})$ & 0.4 & 0.4 & 1.2 & 1.1 & $0.8 \pm 0.1$ & $0.8 \pm 0.1$ \\
\hline Seed thickness (mm) & 2.3 & 2.0 & 4.4 & 4.0 & $3.3 \pm 0.4$ & $3.3 \pm 0.4$ \\
\hline 100 seed weight $(\mathrm{g})$ & 3.8 & 3.8 & 37.3 & 34.3 & $21.4 \pm 5.3$ & $21.3 \pm 5.6$ \\
\hline
\end{tabular}

$\mathrm{EP}$, entire accessions; $\mathrm{CC}$, core collection

(Morimoto et al 2005) and Serbia (Mladenovic et al 2012) were recorded. More recently, Mashilo et al (2017) reported that presence or absence of fruit neck, fruit shape, degree of neck bending and fruit neck length positively correlated the phenotypic variation of South African bottle gourd landraces. In the family of Cucurbitaceae, the significant range of seed and fruit phenotypic variation has been also indicated in C. pepo (Paris 2001), L. siceraria (Morimoto et al 2005) and C. maxima (Balkaya et al 2009).

We aimed to form a $\mathrm{CC}$ representing genetic variation of the entire bottle gourds we possess. In order to determine most appropriate composition in the $\mathrm{CC}$, initially we included the accessions with extreme values such as extremely large and small fruits. The dendrogram and PCA of the EP were used to select the most diverse bottle gourds in Turkish germplasm paying attention their distribution on the dendrogram and PCA and excluding closely positioned genotypes. Additionally, we paid attention to include samples from different regions of the country to represent geographical diversity of country. At first, our selection resulted in total 116 accessions. After that, UPGMA dendrogram and PCA plots were constructed several more times to reduce the number of accessions in the CC. Finally, we terminated selection reaching the 
Table 2- Distribution of 21 qualitative variables of $\boldsymbol{L}$. siceraria from Turkish germplasm

\begin{tabular}{|c|c|c|c|c|c|c|c|}
\hline Characteristics & \multicolumn{7}{|c|}{ Distribution (\%) } \\
\hline \multirow{2}{*}{ Cotyledon position } & \multicolumn{2}{|c|}{ Open } & \multicolumn{2}{|c|}{ Closed } & \multicolumn{3}{|c|}{ Intermediate } \\
\hline & \multicolumn{2}{|c|}{50} & \multicolumn{2}{|c|}{39} & \multicolumn{3}{|c|}{11} \\
\hline \multirow{2}{*}{ Leaf shape } & Oval & Round & Kidney & Heart & \multicolumn{3}{|c|}{ Slightly lobed } \\
\hline & 2 & 15 & 3 & 79 & \multicolumn{3}{|c|}{1} \\
\hline \multirow{2}{*}{ Leaf size } & \multicolumn{2}{|c|}{ Small } & \multicolumn{2}{|c|}{ Big } & \multicolumn{3}{|c|}{ Intermediate } \\
\hline & \multicolumn{2}{|c|}{11} & \multicolumn{2}{|c|}{26} & \multicolumn{3}{|c|}{63} \\
\hline \multirow{2}{*}{ Secondary color on leaf } & \multicolumn{2}{|c|}{ Absent } & \multicolumn{2}{|c|}{ Light green } & \multicolumn{3}{|c|}{ Silvering } \\
\hline & \multicolumn{2}{|c|}{98} & \multicolumn{2}{|c|}{1.5} & & 0.5 & \\
\hline J eaf maroin & & th & & & Dented & & \\
\hline Lear maigin & & & & & 89 & & \\
\hline I eaf lohe & & & Sha & & Intermediate & & Deep \\
\hline Lear love & & & & & 6 & & 1 \\
\hline I eaf nuhescence ventral curface & & & & & Intermediate & & High \\
\hline Leal puoescence, vemtral sumace & & & & & 37 & & 2.5 \\
\hline Jeaf nuhescence dorcal curface & & & & & Intermediate & & High \\
\hline Lear puoescence, dorsal surrace & & & & & 57 & & 23.5 \\
\hline Jeaf hlistering & & & & & Present & & \\
\hline Lear unstering & & & & & 34 & & \\
\hline Flower size & & & & & & ermediate & \\
\hline FIOWEI SIZC & & & & & & 64 & \\
\hline Female flower pocition & & stem & Latera & anch & & Both & \\
\hline remate nower position & & & & & & 4.5 & \\
\hline Peduncle intercectional shane & & & Slightly & igular & Sha & ply angul & \\
\hline r euunce intersectionar sirape & & & & & & 47 & \\
\hline Fruit ribs & & & Supe & cial & Intermediate & & Deep \\
\hline 1 intitios & & & & & 4 & & 0.5 \\
\hline Fruit stem end shane & & ssed & Flat & & Rounded & & ointed \\
\hline 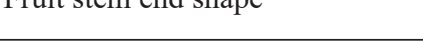 & & & & & 45 & & 5 \\
\hline Fruit bloscom end shane & & ssed & Flat & & Rounded & & ointed \\
\hline 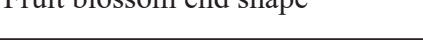 & & & & & 13 & & 14 \\
\hline Fruit skin texture & & th & Finely & nkled & & Netted & \\
\hline 1 1 & & & & & & 2 & \\
\hline Time of maturity & & & & & & ermediate & \\
\hline 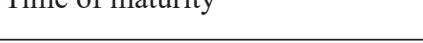 & & & & & & 10 & \\
\hline Predominant fruit skin color & & & & & & ky-Brow & \\
\hline 1 I & & & & & & 2 & \\
\hline Secondary color on fruit skin & & & & & Yellow & & Dther \\
\hline 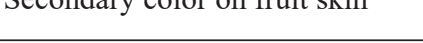 & & & & & 13 & & 2 \\
\hline Pattern of cecondary fruit color & & & Spe & & Spotted & Streaked & Bisectional \\
\hline 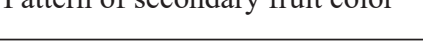 & & & & & 21 & 8 & 3 \\
\hline Fruit shane & $\mathrm{R}$. & $\mathrm{P}$. & Cy. & D. & E. & $\mathrm{C}$. & Cr. N. \\
\hline Tituit silape & 1.5 & 18 & 1 & 8 & 0.5 & 8 & 57 \\
\hline
\end{tabular}

R, Round; E, Elongated; P, Pyriform; Cy, Cylindrical; D, Dumbbell; E, Elliptical; F, Flattened; C, Curved; Cr. N, Crooked Neck 
Table 3- Principal components for 25 quantitative variables of all bottle gourd accessions

\begin{tabular}{|c|c|c|c|c|c|c|c|c|c|c|}
\hline \multirow{2}{*}{ Variable } & \multicolumn{5}{|c|}{ Entire population } & \multicolumn{5}{|c|}{ Core collection } \\
\hline & PCA1 & $P C A 2$ & $P C A 3$ & PCA4 & PCA5 & PCA1 & $P C A 2$ & $P C A 3$ & PCA4 & PCA 5 \\
\hline Eigenvalue & 5.11 & 2.93 & 2.66 & 1.94 & 1.72 & 5.57 & 2.97 & 2.45 & 2.15 & 1.68 \\
\hline Variability (\%) & 20.42 & 11.74 & 10.63 & 7.75 & 6.87 & 22.28 & 11.89 & 9.82 & 8.62 & 6.71 \\
\hline \multirow[t]{2}{*}{ Cumulative \% } & 20.42 & 32.16 & 42.79 & 50.54 & 57.41 & 22.28 & 34.17 & 43.99 & 52.61 & 59.32 \\
\hline & \multicolumn{5}{|c|}{ Contribution of the variables (\%) } & \multicolumn{5}{|c|}{ Contribution of the variables (\%) } \\
\hline Hypocotyl diameter (mm) & 0.67 & 0.36 & 4.96 & 0.11 & 1.63 & 0.28 & 2.72 & 1.42 & 4.36 & 2.91 \\
\hline Hypocotyl length (cm) & 0.02 & 0.29 & 1.38 & 10.09 & 4.96 & 0.49 & 0.71 & 0.98 & 0.12 & 24.13 \\
\hline Cotyledon length $(\mathrm{cm})$ & 1.98 & 0.41 & 11.34 & 0.14 & 14.55 & 2.57 & 2.12 & 5.71 & 1.12 & 10.22 \\
\hline Cotyledon width (cm) & 2.48 & 1.31 & 9.06 & 0.70 & 14.88 & 1.73 & 5.93 & 5.28 & 0.53 & 16.44 \\
\hline Leaf length $(\mathrm{cm})$ & 8.44 & 0.00 & 7.40 & 0.18 & 7.66 & 10.86 & 0.01 & 0.26 & 5.37 & 1.97 \\
\hline Leaf width (cm) & 10.43 & 0.01 & 6.43 & 0.56 & 6.82 & 11.07 & 0.11 & 0.00 & 6.34 & 4.20 \\
\hline Petiole length $(\mathrm{cm})$ & 7.72 & 0.01 & 7.62 & 0.27 & 4.44 & 9.69 & 0.14 & 0.02 & 5.35 & 2.85 \\
\hline Petiole diameter (mm) & 5.42 & 1.23 & 5.88 & 0.18 & 4.86 & 8.37 & 2.66 & 0.03 & 6.69 & 1.38 \\
\hline Main stem diameter (mm) & 0.22 & 4.66 & 0.00 & 2.07 & 3.60 & 0.08 & 6.13 & 9.16 & 0.09 & 3.06 \\
\hline Internodium length (cm) & 0.68 & 3.08 & 0.78 & 8.13 & 5.44 & 0.37 & 4.85 & 9.55 & 2.34 & 0.13 \\
\hline Male flower length $(\mathrm{cm})$ & 6.71 & 1.43 & 1.42 & 1.23 & 3.85 & 8.64 & 0.60 & 0.40 & 0.72 & 0.79 \\
\hline Male flower width (cm) & 6.29 & 0.89 & 1.07 & 1.03 & 2.90 & 6.42 & 0.98 & 0.29 & 2.92 & 2.07 \\
\hline Ovarium diameter (mm) & 2.29 & 6.15 & 3.66 & 0.00 & 1.18 & 2.28 & 2.62 & 1.34 & 2.57 & 8.76 \\
\hline Ovarium length (mm) & 3.90 & 16.91 & 0.50 & 0.04 & 3.60 & 3.36 & 15.97 & 0.55 & 5.26 & 0.26 \\
\hline Female flower length $(\mathrm{cm})$ & 6.50 & 14.25 & 0.07 & 0.39 & 5.71 & 5.40 & 14.43 & 0.43 & 2.81 & 0.14 \\
\hline Female flower width $(\mathrm{cm})$ & 7.12 & 0.70 & 1.91 & 0.46 & 8.39 & 8.49 & 1.95 & 0.20 & 0.20 & 0.08 \\
\hline Male flower blooming time (DAS) & 2.10 & 0.12 & 5.67 & 31.11 & 0.00 & 0.47 & 0.06 & 26.73 & 3.10 & 8.43 \\
\hline Female flower blooming time (DAS) & 2.37 & 0.00 & 4.91 & 30.68 & 0.02 & 0.81 & 0.02 & 25.94 & 1.94 & 8.02 \\
\hline Fruit length $(\mathrm{cm})$ & 1.17 & 13.76 & 3.50 & 0.21 & 0.71 & 0.88 & 6.32 & 0.36 & 6.76 & 2.63 \\
\hline Fruit diameter $(\mathrm{cm})$ & 3.12 & 12.53 & 0.00 & 0.03 & 0.38 & 1.08 & 1.94 & 0.02 & 8.84 & 0.07 \\
\hline Fruit shell thickness (mm) & 3.92 & 1.08 & 0.00 & 0.09 & 0.01 & 3.81 & 2.47 & 0.11 & 1.50 & 0.94 \\
\hline Seed length $(\mathrm{cm})$ & 4.21 & 4.11 & 8.43 & 3.04 & 0.75 & 2.34 & 5.86 & 1.04 & 11.60 & 0.29 \\
\hline Seed width $(\mathrm{cm})$ & 3.63 & 8.49 & 2.38 & 2.25 & 1.14 & 4.52 & 10.17 & 1.56 & 3.22 & 0.07 \\
\hline Seed thickness (mm) & 2.61 & 2.10 & 5.01 & 3.68 & 1.07 & 1.10 & 2.42 & 4.36 & 8.56 & 0.06 \\
\hline 100 seed weight $(\mathrm{g})$ & 6.01 & 6.10 & 6.61 & 3.33 & 1.48 & 4.88 & 8.83 & 4.23 & 7.70 & 0.10 \\
\hline
\end{tabular}

number 100. Correlation between the EP and CC were confirmed by the Mantel test in which " $\mathrm{r}$ " could be in the range of -1 to +1 . When " $r$ " is close to -1 this indicates strong negative correlation between the EP and +1 indicates strong positive correlation. We found " $r$ " $=0.974$ (= normalized Mantel Statistic Z) indicating that there is very strong positive correlation between the EP and CC. The UPGMA dendrogram of $\mathrm{CC}$ revealed their genetic relationships (Figure 2). The dendrogram separated genotypes into two main clusters without any correlation with geographic origin and traits. The upper cluster on the dendrogram contained 50 accessions located closely. The lower cluster consists of the other highly diverse 50 genotypes. In cluster analysis, it was shown that grouping was not closely related with collection sites and phenotypically similar genotypes did not take place in the same group. 


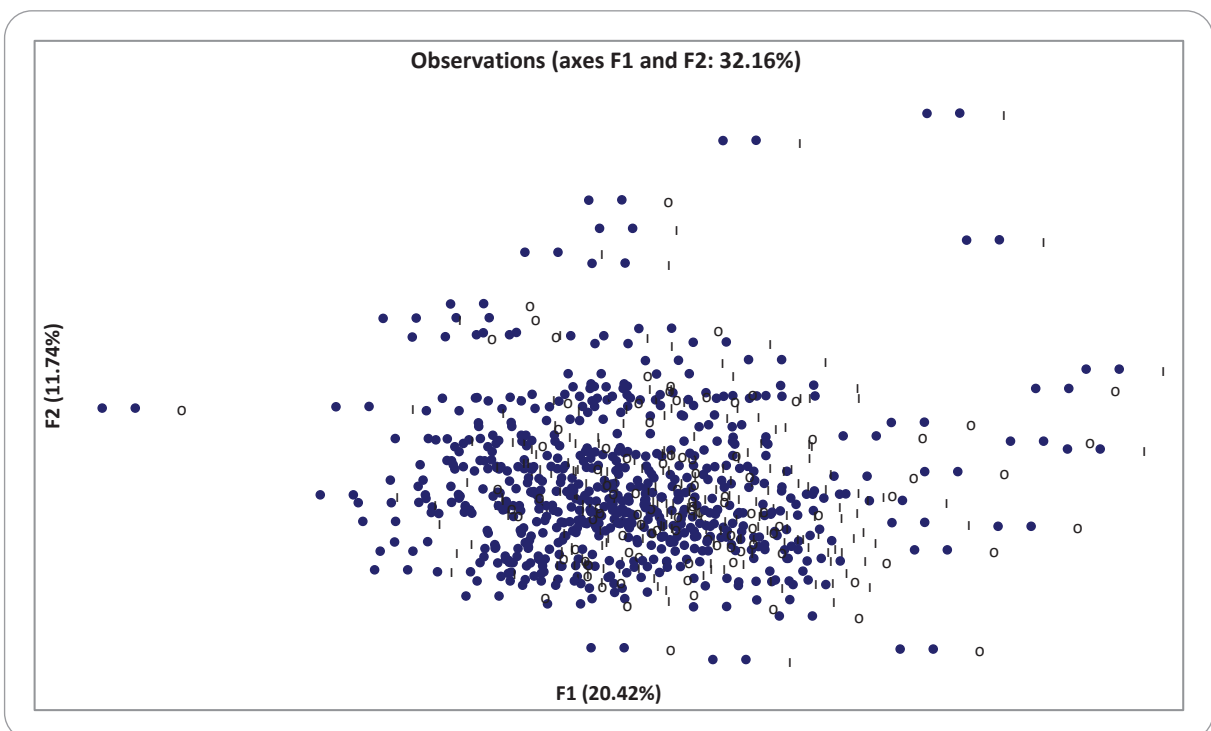

Figure 1- Principal component analysis all genotypes including the core collection collected from Turkey. The first principal component accounted for $\mathbf{2 0 . 4 2 \%}$ of the variability and the second explained an additional $11.74 \%$. ' 0 ' represent the accessions of core collection and ' 1 ' represents remaining

Twenty-five quantitative and 21 qualitative traits of all bottle gourd germplasm were analyzed to establish principal components. The Figure 1. depicts the plot of the first two components of EP including CC. For the 25 qualitative traits, the first five principal components for EP and CC explained a total variation of $57.4 \%$ and $59.3 \%$, respectively, and the percentage variability of the first four principal components is greater than seven from qualitative scoring (Table 3). The first principal component (PC1), predominantly of leaf attributes (leaf length and leaf width) and some flower traits (male flower length, male flower width and female flower width) explained $20.4 \%$ and $22.3 \%$ of the observed variation in the EP and core accessions, respectively. Considering the 21 qualitative variables, the first five principal components for the EP explained a total variation of $34.7 \%$. PC1, predominantly of leaf attributes [leaf pubescence lower (23.8\% of $\mathrm{PC} 1$ variation) and leaf pubescence upper (21.7\% of PC1 variation)] and blossom-end fruit shape (11.4\% of PC1 variation) explained $8.2 \%$ of the total variation. The results of PC analsis for 21 qualitative traits were not presented since qualitative characters were found to be less informative comparing quantitative characters. We have not observed distinct groupings based on geographical origin, plant growth traits nor fruit shape. Neither principle component analysis revealed any groping based on geographical origin.

In this study, phenotypic characteristics have been used for characterization and evaluation of Turkish bottle gourd germplasm with exotic accessions resulted in establishment of a CC representing genetic diversity of the EP. The CC concept was introduced by Frankel (1984) and further the concept was developed by Brown (1989) and van Hintum (1999). Creating a CC requires definition of materials, division of the entire group into sub-groups by stepwise and finally selecting of the entries from each group to establish a core group that represents the diversity of EP as well as possible (van Hintum 1999). It is interesting that this approach does not include geographical distribution although studies show that significance of geographical information as a criterion for 


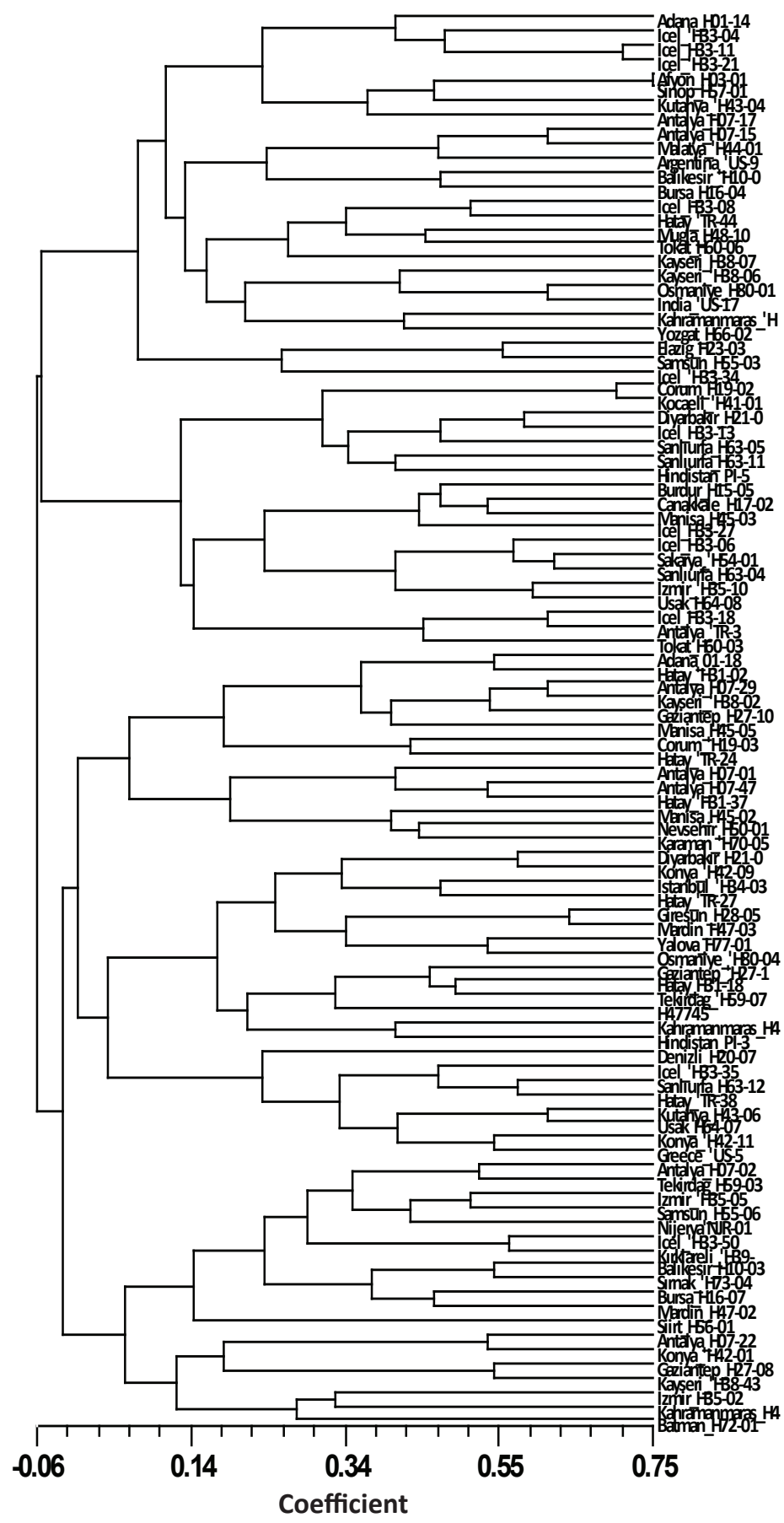

Figure 2- UPGMA depiction of core collection including 100 accessions. Name of the accessions shows source region followed by accessions number 
establishment of CC (Rodrigues et al 2004; De Cristo-araújo et al 2015). We established a CC consisting of 100 accessions following generally the procedure for the selection of a core collection described by van Hintum (1999) and furthermore we included geographical distribution as a criteria during selection. The significant positive correlation (Mantel's " $r "=$ "r"= 0.974) between EP and CC could be shown as successful accomplishment of $\mathrm{CC}$ of bottle gourd. Moreover, the high correlation between EP and CC was supported by PCA.

\section{Conclusions}

In the present study, Turkish bottle gourd accessions collected from all over Turkey and derived from USA and India were morphologically characterized and significant genetic diversity was determined between accessions despite the knowledge that Turkey is not the genetic origin of bottle gourds. Bottle gourd genotypes were characterized for 25 quantitative and 21 qualitative traits. It was concluded that quantitative traits were more discriminative than qualitative traits. Quantitative characteristics of cotyledon, leaf, flower, fruit and seed were found to be more discriminative than others traits. One hundred bottle gourd accessions were chosen based on the morphological characteristics investigated in this study to create a core collection representing the majority of the genetic variation of all genotypes within the entire Turkish bottle gourd germplasm collection.

\section{Acknowledgements}

The study was supported by The Scientific and Technological Research Council of Turkey (TUBITAK) Project No: 111O117. The authors thank TUBITAK for their financial support. In addition, authors deeply thankful to Dr. Andrew THOMPSON from Cranfield University for proofreading whose efforts have significantly improved the quality and accuracy of the information and language of the manuscript.

\begin{tabular}{|llllll|}
\hline \multicolumn{7}{|l|}{ Abbreviations and Symbols } \\
\hline $\mathrm{cm}$ & centimeter & $\mathrm{kg}$ & kilogram & $\mathrm{N}$ & Nitrogen \\
$\mathrm{ha}^{-1}$ & Per Hectare & $\mathrm{m}$ & meter & $\mathrm{P}_{2} \mathrm{O}_{5}$ & Phosphorus pentoxide \\
$\mathrm{K}_{2} \mathrm{O}$ & Potassium oxide & $\mathrm{mm}$ & millimeter & Subsp & Subspecies \\
\hline
\end{tabular}

\section{References}

Balkaya A, Yanmaz R \& Özbakir M (2009). Evaluation of variation in seed characters of Turkish winter squash (Cucurbita maxima) populations. New Zealand Journal of Crop and Horticultural Science 37(3): 167-178

Biodiversity International for Cucurbitaceae (2007). Guidelines for the development of crop descriptor lists. Bioversity Technical Bulletin Series. Biodiversity International, Rome, Italy

Brown A H D (1989). Core collections: a practical approach to genetic resources management. Genome 31(4): $818-824$

De Cristo-araújo M, Rodrigues D P, Astolfi-filho S \& Clement C R (2015). Peach palm core collection in Brazilian Amazonia. Crop Breeding and Applied Biotechnology 15: 18-25
Decker-Walters D S, Wilkins-Ellert M, Chung S M \& Staub J E (2004). Discovery and genetic assessment of wild bottle gourd [Lagenaria siceraria (Mol.) Standley; Cucurbitaceae] from Zimbabwe. Economic Botany 58(4): 501-508

Frankel O H (1984). Genetic perspectives of germplasm conservation. In Genetic Manipulation: Impact on Man and Society (W.K. Arber, K. Llimensee, W.J. Peacock and P. Starlinger, Eds.). Cambridge University Press, Cambridge, UK, pp. 161-170

Given D R (1987). What the conservationist requires of ex situ collections. In: Branwell D, Hamann O, Heywood $\mathrm{V}$, Synge H., editors. Botanic gardens and the world conservation strategy. Academic Press, London, pp. 103-116

Gürcan K, Say A, Yetisir H \& Denli N (2015). A study of genetic diversity in bottle gourd [Lagenaria siceraria 
(Molina) Standl.] population, and implication for the historical origins on bottle gourds in Turkey. Genetic Resources Crop Evolution 62(3): 321-333

Kistler L, Montenegro A, Smith B D, Grifford J A, Green R E, Newsom L A \& Shapiro B (2014). Transoceanic drift and the domestication of African bottle gourds in the Americas. Proceedings of the National Academy of Sciences of the United States of America 111: 2937-2941

Loukou A L, Gnakri D, Djè Y, Kippré A V, Malice M J P B, Baudoin J-P \& Zoro Bi I A (2007). Marie et al. Page 53 Macronutrient composition of three cucurbit species cultivated for seed consumption in Côte d'Ivoire. African Journal of Biotechnology 6: 529-533

Mashilo J, Shimelis H A, Odindoa A O \& Amelework B A (2017). Genetic differentiation of bottle gourd [Lagenaria siceraria (Molina) Standl.] landraces assessed by fruit qualitative traits and simple sequence repeat markers. Scientia Horticulturae 216: 1-11

Mladenovic E, Berenji J, Ognjanov V, Ljubojević M \& Čukanović A (2012). Genetic variability of bottle gourd (Lagenaria siceraria (Mol.) Standley) and its morphological characterization by multivariate analysis. Archives of Biological Sciences 64(2): 573-583

Morimoto Y, Maundu P, Fujimaki H \& Morishima H (2005). Diversity of landraces of the white-flowered gourd (Lagenaria siceraria) and its wild relatives in Kenya: fruit and seed morphology. Genetic Resources and Crop Evolution 52(6): 737-747

Paris H S (2001). Characterization of Cucurbita pepo collection at the Newe Ya'ar Research Center, Israël. Plant Genetic Resources Newsletter 126: 41-45
Rodrigues D P, Astolfi-Filho S \& Clement C R (2004). Molecular marker mediated validation of morphologically defined landraces of Pejibaye (Bactris gasipaes) and their phylogenetic relationships. Genetic Resources and Crop Evolution 51: $871-882$

Rohlf F J (2000). NTSYS-pc. Numerical taxonomy and multivariate analysis system, version 2.1. Exeter Software, Setauket, New York, USA

Schlumbaum A \& Vandorpe P (2012). A short history of Lagenaria siceraria (bottle gourd) in the Roman provinces: morphotypes and archaeogenetics. Vegetation History and Archaeobotany 21(6): 499509

van Hintum T J L (1999). The general methodology for creating a core collection. In Johnson RC and Hodgkin $\mathrm{T}$ (Eds.) Core collections for today and tomorrow. IPGRI, Roma, pp. 10-17

Yetisir H \& Uygur V (2009). Plant growth and mineral element content of different gourd species and watermelon under salinity stress. Turkish Journal of Agriculture and Forestry 33(1): 65-77

Yetisir H, Sari N \& Yücel S (2003). Rootstock resistance to Fusarium wilt and effect on fruit yield and quality of watermelon. Phytoparasitica 31(2): 163-169

Yetisir H, Sakar M \& Serce S (2008). Collection and morphological characterization of Legenaria siceraria germplasm form the Mediterranean Region of Turkey. Genetic Resources and Crop Evolution 55(8): 12571266 